\title{
The predictive value of cognitive impairments measured at the start of clinical rehabilitation for health status 1 year and 3 years poststroke
}

Citation for published version (APA):

Verhoeven, C. L., Schepers, V. P., Post, M. W., \& van Heugten, C. M. (2011). The predictive value of cognitive impairments measured at the start of clinical rehabilitation for health status 1 year and 3 years poststroke. International Journal of Rehabilitation Research, 34(1), 38-43.

https://doi.org/10.1097/MRR.0b013e32833ba577

Document status and date:

Published: 01/03/2011

DOI:

10.1097/MRR.0b013e32833ba577

Document Version:

Publisher's PDF, also known as Version of record

Document license:

Taverne

Please check the document version of this publication:

- A submitted manuscript is the version of the article upon submission and before peer-review. There can be important differences between the submitted version and the official published version of record.

People interested in the research are advised to contact the author for the final version of the publication, or visit the DOI to the publisher's website.

- The final author version and the galley proof are versions of the publication after peer review.

- The final published version features the final layout of the paper including the volume, issue and page numbers.

Link to publication

\footnotetext{
General rights rights.

- You may freely distribute the URL identifying the publication in the public portal. please follow below link for the End User Agreement:

www.umlib.nl/taverne-license

Take down policy

If you believe that this document breaches copyright please contact us at:

repository@maastrichtuniversity.nl

providing details and we will investigate your claim.
}

Copyright and moral rights for the publications made accessible in the public portal are retained by the authors and/or other copyright owners and it is a condition of accessing publications that users recognise and abide by the legal requirements associated with these

- Users may download and print one copy of any publication from the public portal for the purpose of private study or research.

- You may not further distribute the material or use it for any profit-making activity or commercial gain

If the publication is distributed under the terms of Article 25fa of the Dutch Copyright Act, indicated by the "Taverne" license above, 


\section{The predictive value of cognitive impairments measured at the start of clinical rehabilitation for health status 1 year and 3 years poststroke Clara L. Verhoeven ${ }^{\mathrm{a}}$, Vera P. Schepers ${ }^{\mathrm{a}, \mathrm{b}}$, Marcel W. Post ${ }^{\mathrm{b}}$ and Caroline M. van Heugten ${ }^{b, c}$}

The objective of this study was to investigate the value of screening for cognitive functions at the start of an inpatient rehabilitation programme to predict the health status 1 and 3 years poststroke. In this longitudinal cohort study of stroke patients in inpatient rehabilitation data of 134 participants were analysed. Cognitive and clinical data were collected after admission to inpatient rehabilitation treatment. Data on health status were collected at 1 and 3 years post stroke. Cognitive functioning was assessed with the Cambridge Cognitive Examination (CAMCOG). Health status was assessed with the Stroke-Adapted Sickness Impact Profile. Statistical analyses included descriptive statistics, Pearson correlations and multiple regression analysis. One year poststroke, the CAMCOG dimensions of orientation $(\beta=-0.21)$, Perception $(\beta=-0.16)$ and Memory $(\beta=-0.16)$, as well as age and motor function were significant predictors of health status. Cognitive variables alone explained $2.5-10.3 \%$ of the variance. Three years poststroke, CAMCOG Perception $(\beta=-0.19$ and -0.18$)$ and Language $(\beta=-0.15)$, as well as age, type of stroke and motor function were significant predictors of health status, and the cognitive variables alone explained $1.7-10.9 \%$ of the variance. CAMCOG scores were significant predictors of long-term health status in patients with stroke, although the amount of explained variance was small.

Die vorliegende Studie $\mathrm{m}$-chte untersuchen, welchen Stellenwert das Screening der kognitiven Funktionen zu Beginn eines stationđren Reha-Programms hat, um den Gesundheitsstatus bei Patienten 1 Jahr bzw. 3 Jahre nach einem Schlaganfall vorhersagen zu k-nnen. Eine longitudinale Kohortenstudie mit Schlaganfallpatienten in stationorer Reha-Behandlung. Die Daten von 134 Teilnehmern wurden analysiert. Kognitive und klinische Daten wurden nach der Einweisung der Patienten in Reha-Zentren zwecks stationđrer Behandlung erfasst. Die Daten zum Gesundheitsstatus wurden 1 Jahr bzw. 3 Jahre nach einem Schlaganfall erfasst. Die kognitive Funktionsfohigkeit wurde unter Zuhilfenahme des Tests Cambridge Cognitive Examination (CAMCOG) bewertet. Der Gesundheitsstatus wurde mit Hilfe des fr Schlaganfallpatienten angepassten Erkrankungs-Auswirkungs-Profils (Stroke-Adapted Sickness Impact Profile) bewertet. Die statistischen Analysen umfassten deskriptive Statistiken, den Korrelationstest nach Pearson und die multiple
Regressionsanalyse. Ein Jahr nach dem Schlaganfall erwiesen sich die CAMCOG-Dimensionen Orientierung $(\beta=-0.21)$, visuelle Perzeption $(\beta=-0.16)$ und Erinnerung $(\beta=-0.16)$ sowie das Alter und die Motorik als signifikante Prodiktoren des Gesundheitsstatus. Die kognitiven Variablen allein waren fr 2.5-10.3\% der Varianz verantwortlich. Drei Jahre nach dem Schlaganfall erwiesen sich die CAMCOG-Dimensionen Perzeption $(\beta=-0.19$ und -0.18$)$ und Sprache $(\beta=-0.15)$ sowie das Alter, die Art des Schlaganfalls und die Motorik als signifikante Prðdiktoren des Gesundheitsstatus, und die kognitiven Variablen allein waren fr 1.7-10.9\% der Varianz verantwortlich. Die CAMCOG-Scores waren signifikante Prðdiktoren des langfristigen Gesundheitsstatus bei Schlaganfallpatienten, obwohl der Anteil der erklorten Varianz gering war.

El objetivo de este estudio fue investigar el valor de la exploraciœn sistemÃtica de las funciones cognitivas al inicio de un programa hospitalario de rehabilitaciœn, con el fin de predecir el estado de salud tras 1 y 3 años de haber padecido el paciente un accidente cerebrovascular. Se trata de un estudio longitudinal de una cohorte de pacientes que padecieron un accidente cerebrovascular y que se recibúan tratamiento hospitalario de rehabilitaciœn. Se analizaron los datos correspondientes a 134 pacientes. Los datos cognitivos y clÚnicos se recogieron en el momento del ingreso para el tratamiento hospitalario de rehabilitaciœn. Los datos sobre el estado de salud se recolectaron tras 1 y 3 años de ocurrido el accidente cerebrovascular. La funciœn cognitiva se valorœ mediante el Examen Cognitivo de Cambridge (CAMCOG); y el estado de salud, con el Perfil de las Consecuencias de la Enfermedad, Adaptado Para el Ictus. Entre los anÃlisis estadÚsticos se realizaron estadÚsticas descriptivas y los anÃlisis de correlaciones de Pearson y de regresiœn. Un año después de ocurrido el accidente cerebrovascular, las dimensiones del CAMCOG correspondientes a la orientaciœn $(\beta=-0.21)$, la percepciœn $(\beta=-0.16)$ y la memoria $(\beta=-0.16)$, asÚ como la edad y el funcionamiento motor fueron factores pronœstico importantes del estado de salud. Las variables cognitivas justificaron entre el $\mathbf{2 . 5}$ y el $\mathbf{1 0 . 3} \%$ de la varianza. Tres años después del accidente cerebrovascular, las dimensiones del CAMCOG correspondientes a la percepciœn $(\beta=-0.19$ y -0.18$)$ y el lenguaje $(\beta=-0.15)$, asÚ como la edad, el tipo de accidente cerebrovascular 
y el funcionamiento motor fueron factores pronœstico importantes del estado de salud. Las variables cognitivas justificaron entre el 1.7 y el $10.9 \%$ de la varianza. Los puntajes del CAMCOG fueron factores pronœstico importantes del estado de salud a largo plazo de los pacientes que han padecido un ictus, si bien la magnitud de la varianza explicable fue pequeña.

Cette étude avait pour objet d'étudier la valeur du dépistage pour les fonctions cognitives au début d'un programme de rééducation de patients hospitalisés pour prédire l'état de santé 1 an et 3 ans après un AVC. ètude de cohorte longitudinale de patients victimes d'AVC en rééducation durant un séjour hospitalier. Les données de 134 participants ont été analysées. Les données cognitives et cliniques ont été recueillies après admission Á un traitement de rééducation en séjour hospitalier.

Les données sur l'état de santé ont été recueillies 1 an et 3 ans après l'AVC. Les fonctions cognitives ont été évaluées par l'examen CAMCOG (Cambridge Cognitive

Examination). L'état de santé a été évalué avec le profil

Stroke-Adapted Sickness Impact. Les analyses statistiques incluaient les statistiques descriptives, les corrélations de Pearson et l'analyse par régression multiple. Un an après AVC, les dimensions CAMCOG d'orientation $(\beta=-0.21)$, de perception $(\beta=-0.16)$ et de mémoire $(\beta=-0.16)$, ainsi que l'âge et les fonctions motrices constituaient

\section{Introduction}

The number of people suffering strokes is increasing, and those who survive are often confronted with residual physical and cognitive impairments, and experience problems in quality of life (Sturm et al., 2004).

Recently, more attention has been directed towards relationships between cognitive impairments and poststroke health status and quality of life (King, 1996; Kwa et al., 1996; Jonkman et al., 1998; Hochstenbach et al., 2001; Larson et al., 2003; Sturm et al., 2004; Visser-Keizer, 2004; van Zandvoort et al., 2005; Haacke et al., 2006; Nys et al., 2006; Patel et al., 2007). Assessment of cognitive functioning in the early phase of stroke is important because cognitive impairments may have a negative influence on rehabilitation outcome (Dick et al., 1984; Heruti et al., 2002; Surh and Grace, 2004; Nys et al., 2005). In addition, results of assessment of cognitive functioning at the start of rehabilitation can be valuable in the selection of treatment options, and can provide guidance for the therapists in managing cognitively impaired patients (Te Winkel-Witlox et al., 2008). The predictive value of cognitive tests early after stroke for long-term health status and quality of life is, however, not clear. Earlier studies on this topic used different approaches to cognitive assessment, including studies using extensive test batteries. These studies have found visual perception/ construction (Nys et al., 2006), visual search and d'importants facteurs prédictifs de l'état de santé. Les variables cognitives expliquaient Á elles seules $2.5-10.3 \%$ de la variance. Trois ans après l'AVC, les dimensions CAMCOG de perception $(\beta=-0.19$ et -0.18$)$ et de langage $(\beta=-0.15)$, ainsi que l'âge, le type d'accident vasculaire cérébral et les fonctions motrices constituaient d'importants facteurs prédictifs de l'état de santé, et les variables cognitives seules expliquaient $1.7-10.9 \%$ de la variance. Les scores CAMCOG sont des facteurs prédictifs importants de l'état de santé au long terme chez les patients ayant subi un AVC, bien que l'importance de la variance expliquée soit limitée. International Journal of Rehabilitation Research 34:38-43 ๔ 2011 Wolters Kluwer Health | Lippincott Williams \& Wilkins.

International Journal of Rehabilitation Research 2011, 34:38-43

Keywords: cognition, health status, prognosis, stroke

aDepartment of Stroke Rehabilitation, ${ }^{\text {b }}$ Rehabilitation Centre De Hoogstraat, Centre of Excellence in Rehabilitation Medicine, and Rudolf Magnus Institute for Neuroscience, Department of Rehabilitation, University Medical Centre Utrecht, Utrecht and ' School for Mental Health and Neuroscience, Maastricht University, Maastricht, The Netherlands

Correspondence to Clara L. Verhoeven, MSc, Rehabilitation Center De Hoogstraat, Department of Stroke Rehabilitation, Rembrandtkade 10, 3583 TM Utrecht, Utrecht, The Netherlands

Tel: + 3130 2561211; fax: +3130 2511344;

e-mail: k.verhoeven@dehoogstraat.nl

Received 28 January 2010 Accepted 17 April 2010

visuospatial sequencing (Hochstenbach et al., 2001) and reasoning abilities and memory (Visser-Keizer, 2004) to be predictive of quality of life, although one other study found no predictive value of cognitive functioning for quality of life (van Zandvoort et al., 2005).

Extensive testing is, however, not always possible because of time and costs aspects. Screening for cognitive impairments can be a more feasible way of assessing cognitive impairments. Studies using cognitive screening instruments have yielded contradictory results. The Mini Mental State Examination (MMSE) was related to quality of life 4 years poststroke in a hospital-based population (Haacke et al., 2006) and in a community-based population, 1-3 years post stroke (Patel et al., 2007). One study used the Repeatable Battery for the Assessment of Neuropsychological Symptoms in a rehabilitation population and showed that the Language Index had predictive value for quality of life at 6 months after discharge from inpatient treatment (Larson et al., 2003). Assessment of cognitive functioning with the Cambridge Cognitive Examination (CAMCOG) total score in a hospital-based population revealed a significant bi-variate relation between global cognitive impairment (CAMCOG total score below 80) and decreased quality of life 2 years post stroke, but in stepwise regression analysis, only functional health (Rankin scale), infarct volume and aphasia were determinants of quality of life (Kwa et al., 1996). 
Most of these studies using cognitive screening instruments have assessed long-term health status and quality of life in persons with stroke in relation to global cognitive functioning (Kwa et al., 1996; Haacke et al., 2006; Patel et al., 2007), although the instruments that were used consist of different scales, allowing assessment of cognitive problems in various domains. Only one study did look into the relationship between long-term health-related quality of life and separate cognitive domains, but only for as long as 6 months after discharge from inpatient treatment (Larson et al., 2003). The predictive value of cognitive impairments measured in the early phase of stroke for long-term quality of life might be greater for a combination of domain scores than for a single total score and might reveal the cognitive domains that are most predictive of long-term quality of life. The aim of this study was to examine the value of screening cognitive domains at the start of an inpatient rehabilitation programme in predicting health status 1 and 3 years post stroke.

\section{Methods \\ Participants}

Stroke patients consecutively admitted to four Dutch rehabilitation centres were eligible for the study. Inclusion criteria were (i) admittance for inpatient rehabilitation, (ii) first-ever stroke, (iii) one-sided supratentorial lesion and (iv) age over 18 years. Exclusion criteria were (i) disabling co-morbidity (pre-stroke BI below 18), (ii) insufficient Dutch language skills and (iii) communication deficits (Utrecht Communication Observation score below 4, on a 1-5 scale) (Back et al., 2006). Patients with severe aphasia were thus excluded.

The Medical Ethics committees of the University Medical Centre Utrecht and the participating rehabilitation centres approved the study protocol.

\section{Procedure}

Individuals were asked to participate in the study by their rehabilitation physician at the start of inpatient rehabilitation. Informed consent was obtained from all participants.

The first assessment, including demographic characteristics, motor and cognitive functioning, took place as soon as possible after admission to inpatient rehabilitation. The second and the third assessments, including measurement of health status, took place 1 and 3 years post stroke, by interviewing the participants. All assessments were performed by trained test assistants.

\section{Measures}

Demographic and stroke characteristics were recorded from medical files, and included age, sex, educational level, type and side of stroke. Educational level was dichotomized into 'low' and 'high' (high meaning having completed at least secondary school).
Motor impairment was assessed with the Motricity Index (MI) (Collen et al., 1990). The MI score ranges from 0 (paralysis) to 100 (normal strength).

Functional independence was assessed with the Barthel Index (BI) (Collin et al., 1998). This is a 10-item measure including self-care, mobility and continence, with a total score between 0 (complete dependence) and 20 (independent).

Cognitive functioning was measured with a screening measure, the CAMCOG. The CAMCOG is the cognitive part of the Cambridge Mental Disorders of the Elderly Examination (Roth et al., 1986; Derix et al., 1991). The CAMCOG consists of 59 items with a best possible score of 106, and includes eight subscales that assess the following domains: Orientation, Language, Memory, Attention, Calculation, Praxis, Abstract Thought and Perception. Subscale scores as well as a total CAMCOG score were calculated and used in this study. A cut-off value of 79/80 for the total score is used to differentiate between good and poor cognitive functioning (Roth et al., 1986). The CAMCOG has been shown to be a feasible (Kwa et al., 1996) and valid screening instrument in stroke populations (Roth et al., 1986; De Koning et al., 1998).

The assessment with the CAMCOG was done for research purposes only and there was no relation between this assessment and choice of rehabilitation treatment.

Health status was measured by means of the StrokeAdapted Sickness Impact Profile (SA-SIP30). The SASIP30 is a short version of the SIP136, and consists of 30 items in two dimensions and a total score. The Physical dimension covers self-care and mobility, whereas the Psychosocial dimension covers social interaction, emotion and communication. The SA-SIP30 is in the literature often addressed as a health-related quality of life measure, but health status is a more appropriate term because the SA-SIP30 mainly concerns the physical aspects of health (van Straten et al., 2000). The SA-SIP30 has been shown to be a short, feasible and well validated measure to assess health status after stroke (van Straten et al., 1997; van de Port et al., 2004).

\section{Statistical analyses}

Descriptive statistics were used to analyse the characteristics and functioning of the study group. Bivariate analysis using the Pearson product-moment correlation coefficients was applied to describe the relations between the dependent measure and all clinical and cognitive variables.

Hierarchical linear regression analysis was performed using the backward procedure, including all CAMCOG subscale scores and all other variables that were related $(P<0.1)$ to SA-SIP30 scores. This gave us the opportunity to examine the way cognitive functioning predicts health status, as well as its predictive capacity after correction for the clinical variables of age, sex, educational level, side and type of stroke and motor impairment. 
The percentage of variance explained by CAMCOG subscales together, additional to the variance explained by other determinants, was computed and tested for significance $(P<0.05)$. Analyses were performed with the SPSS statistical software package (version 15.0; SPSS, Chicago, Illinois, USA).

\section{Results}

A total of 209 participants were included in the study. Thirteen participants died before the 3-year follow-up, 17 had a recurrent stroke, 37 refused further participation and eight had missing scores for one or more measures. Thus, complete datasets from 134 participants were available for analysis.

The characteristics of the participants at baseline are shown in Table 1. The participants were relatively young. The mean BI was 14.7 (SD 4.3), indicating moderate disability

Table 1 Participant characteristics at admission to inpatient rehabilitation

\begin{tabular}{lc}
\hline Baseline characteristics & Participants $(n=134)$ \\
\hline Clinical variables & 59 \\
Sex, \% male & 56.511 .3 \\
Age, mean SD & 22.4 \\
Education, \% high education level & 58.128 .0 \\
Motricity index, mean SD & 59.7 \\
Side of stroke, \% right & 68.7 \\
Type of stroke, \% infarction & \\
Descriptive variables & 14.74 .3 \\
Barthel index, mean SD & $45(34-60)$ \\
Days between stroke and assessment, median (IOR) & \\
Cognitive variables (CAMCOG): median (IOR) & $9(9-10)$ \\
Orientation (score range 0-10) & $26(24-28)$ \\
Language (score range 0-30) & $21(19-24)$ \\
Memory (score range 0-27) & $7(6-7)$ \\
Attention (score range 0-7) & $11(10-12)$ \\
Praxis (score range 0-12) & $2(2-2)$ \\
Calculation (score range 0-2) & $6(6-7)$ \\
Abstract thinking (score range 0-8) & $8(7-9.25)$ \\
Perception (score range 0-10) & $90(83-96)$ \\
Total (score range 0-106) &
\end{tabular}

CAMCOG, Cambridge cognitive examination; IQR, Inter quartile range. at the start of inpatient rehabilitation. The median CAMCOG total score of 90 (interquartile range 83-96) indicates rather high cognitive functioning for stroke patients.

\section{Bivariate analysis}

The bivariate correlation coefficients between the independent variables and the SA-SIP30 scores are presented in Table 2. At 1 year post stroke, Perception was the cognitive variable that was most strongly correlated to health status (the SA-SIP30 Total score and the SA-SIP30 Physical dimension). Orientation was significantly correlated to the SA-SIP30 Psychosocial dimension and Memory was significantly correlated to the SA-SIP30 Physical dimension. This positive correlation indicates that participants with better memory perceived poorer self-care and mobility. The MI was significantly correlated to all SASIP30 scores. Type of stroke was significantly correlated to the SA-SIP30 Total score and the SA-SIP30 Physical dimension, and age was significantly correlated to the SASIP30 Physical dimension.

At 3 years post stroke, Perception showed a significant correlation to the SA-SIP30 Total score and the SA-SIP30 Physical dimension. Praxis showed a significant correlation with the SA-SIP30 Physical dimension.

The MI and type of stroke were significantly correlated to the SA-SIP30 Total score and the SA-SIP30 Physical dimension.

\section{Multivariate analysis}

The results of the multivariate regression analyses are presented in Table 3. At 1 year post stroke, all CAMCOG scores together explained $6.9 \%$ of the variance of SA-SIP30 Total score, $10.3 \%$ of the variance of the SA-SIP30 Physical dimension and $2.5 \%$ of the variance of the SA-SIP30 Psychosocial dimension. Motor functioning was the strongest determinant of health status. Age was a determinant of

Table 2 Bivariate correlations for the clinical and neuropsychological predictors and the measure of health status 1 and 3 years post stroke

\begin{tabular}{|c|c|c|c|c|c|c|}
\hline & \multicolumn{3}{|c|}{ SA-SIP30, 1 year post stroke } & \multicolumn{3}{|c|}{ SA-SIP30, 3 years post stroke } \\
\hline & Total score & Physical dimension & Psychosocial dimension & Total score & Physical dimension & Psychosocial dimension \\
\hline CAMCOG Orientation & -0.132 & -0.057 & $-0.180 *$ & -0.058 & -0.022 & 0.017 \\
\hline CAMCOG Language & -0.012 & 0.066 & -0.105 & -0.112 & -0.024 & -0.156 \\
\hline CAMCOG Memory & 0.048 & $0.173 *$ & -0.124 & -0.025 & 0.086 & -0.128 \\
\hline CAMCOG Concentration & 0.074 & 0.147 & -0.031 & 0.003 & 0.086 & -0.071 \\
\hline CAMCOG praxis & -0.126 & -0.137 & -0.064 & -0.129 & $-0.199 *$ & -0.023 \\
\hline CAMCOG Calculation & 0.011 & 0.001 & 0.028 & -0.103 & -0.069 & -0.046 \\
\hline CAMCOG Abstraction & -0.088 & -0.050 & -0.104 & -0.118 & -0.121 & -0.090 \\
\hline CAMCOG Perception & $-0.244 * *$ & $-0.195^{*}$ & -0.164 & $0 .-269 * *$ & $-0.295 * *$ & -0.108 \\
\hline CAMCOG total & 0.074 & 0.033 & -0.168 & -0.150 & -0.077 & -0.150 \\
\hline Sex & -0.023 & -0.044 & -0.008 & -0.009 & -0.008 & 0.037 \\
\hline Age & 0.127 & $0.224 * *$ & -0.054 & 0.168 & $0.200 *$ & 0.014 \\
\hline Education & -0.134 & -0.125 & -0.133 & -0.160 & -0.167 & -0.130 \\
\hline Motricity index & $-0.443^{* *}$ & $-0.506 * *$ & $-0.238 * *$ & $-0.345^{* *}$ & $-0.493^{* *}$ & -0.077 \\
\hline Side of stroke & 0.121 & 0.119 & 0.083 & 0.128 & 0.114 & 0.037 \\
\hline Type of stroke & $-0.170 *$ & $-0.234 * *$ & -0.053 & $-0.248 * *$ & $-0.301 * *$ & -0.082 \\
\hline
\end{tabular}

CAMCOG, Cambridge cognitive examination; SA-SIP30, stroke-adapted sickness impact profile.

$* P<0.05$.

$* * P<0.01$. 
Table 3 Hierarchical backward regression for the clinical and neuropsychological predictors (CAMCOG subscales) of health status 1 and 3 years post stroke

\begin{tabular}{|c|c|c|c|c|c|c|c|c|c|c|c|c|}
\hline \multirow[b]{3}{*}{ CAMCOG } & \multicolumn{6}{|c|}{ SA-SIP30, 1 year post stroke } & \multicolumn{6}{|c|}{ SA-SIP30, 3 years post stroke } \\
\hline & \multicolumn{2}{|c|}{ Total score } & \multicolumn{2}{|c|}{ Physical dimension } & \multicolumn{2}{|c|}{ Psychosocial dimension } & \multicolumn{2}{|c|}{ Total score } & \multicolumn{2}{|c|}{ Physical dimension } & \multicolumn{2}{|c|}{ Psychosocial dimension } \\
\hline & Beta & $P$ & Beta & $P$ & Beta & $P$ & Beta & $P$ & Beta & $P$ & Beta & $P$ \\
\hline Orientation & -0.151 & 0.05 & -0.151 & 0.06 & -0.209 & 0.01 & & & & & & \\
\hline Language & & & & & & & & & & & -0.149 & 0.09 \\
\hline Memory & & & 0.164 & 0.04 & & & & & & & & \\
\hline \multicolumn{13}{|l|}{ Concentration } \\
\hline \multicolumn{13}{|l|}{ Praxis } \\
\hline \multicolumn{13}{|l|}{ Calculation } \\
\hline \multicolumn{13}{|l|}{ Abstraction } \\
\hline Perception & -0.160 & 0.04 & \multirow{2}{*}{\multicolumn{2}{|c|}{10.3}} & & & -0.187 & 0.02 & -0.180 & 0.02 & & \\
\hline Explained variance (\%) & 6.9 & & & & \multicolumn{2}{|c|}{2.5} & 6.5 & & \multicolumn{2}{|c|}{10.9} & \multicolumn{2}{|c|}{1.7} \\
\hline \multicolumn{13}{|l|}{ Sex } \\
\hline Age & & & 0.261 & 0.00 & & & 0.181 & 0.03 & 0.205 & 0.01 & & \\
\hline \multicolumn{13}{|l|}{ Education } \\
\hline Motricity Index & -0.422 & 0.00 & -0.539 & 0.00 & -0.271 & 0.001 & -0.321 & 0.00 & -0.461 & 0.00 & & \\
\hline \multicolumn{13}{|l|}{ Side of stroke } \\
\hline Type of stroke & \multirow{2}{*}{\multicolumn{2}{|c|}{24.1}} & \multirow{2}{*}{\multicolumn{2}{|c|}{34.8}} & \multirow{2}{*}{\multicolumn{2}{|c|}{9.2}} & \multirow{2}{*}{\multicolumn{2}{|c|}{17.7}} & -0.136 & 0.08 & \multirow{2}{*}{\multicolumn{2}{|c|}{1.5}} \\
\hline Total explained variance (\%) & & & & & & & & & 34 & & & \\
\hline
\end{tabular}

Only significant relations are shown.

CAMCOG, Cambridge cognitive examination; SA-SIP30, stroke-adapted sickness impact profile.

poorer health status. CAMCOG Orientation was a significant determinant of the SA-SIP30 Psychosocial dimension, whereas CAMCOG Memory was a significant predictor of the SA-SIP30 Physical dimension and CAMCOG Perception was a predictor of SA-SIP30 Total score.

At 3 years post stroke, CAMCOG Perception was a significant determinant of SA-SIP30 Total score and of the SASIP30 Physical dimension. CAMCOG Language was the only predictor of the SA-SIP30 Psychosocial dimension. At this measurement, all CAMCOG scores together explained $6.5 \%$ of the variance of the SASIP30 Total score, $10.9 \%$ of the variance of the SA-SIP30 Physical dimension, and $1.7 \%$ of the variance of the SA-SIP30 Psychosocial dimension.

\section{Discussion}

Our study showed that screening for cognitive problems with the CAMCOG at the start of an inpatient rehabilitation program does have predictive value for health status, even after 3 years. The CAMCOG domains of Orientation, Memory and Perception were significant determinants of health status 1 year post stroke. The Perception and Language domains of the CAMCOG were significant predictors of health status 3 years post-stroke.

Our results expand on those of Kwa et al. (Kwa et al., 1996), who found a significant and moderate effect (Effect size 0.6) of cognitive impairment on health status 2 years poststroke, but who used the CAMCOG total score only, and used a single-item visual analogue scale scale to rate the health status. We analysed separate domain score and assessed the health status with a standardized multidimensional measure (van de Port et al., 2004).

The predictors in our study are in agreement with those reported in the literature, as far as perception (Nys et al., 2006), memory (Visser-Keizer, 2004) and language (Larson et al., 2003) are concerned. Orientation as a specific cognitive domain has not been assessed before in relation to health status. Although orientation is part of the total score of the MMSE, the contribution of orientation to the total score was not specified in studies of cognitive functioning and quality of life (Haacke et al., 2006; Patel et al., 2007). Our study showed that this cognitive domain is associated with health status, and it is quite easy to imagine that having orientation problems affects all daily activities.

The amount of variance explained by the cognitive functions was rather small (1.7-10.9\%). After the addition of clinical variables, the explained variance of health status increased to $34.8 \%$. This is in agreement with other studies using multiple regression analysis, showing that motor functioning and age (Nys et al., 2006) or physical health (Rankin) (Kwa et al., 1996) are strong predictors of health status.

Overall, screening for cognitive impairments with a measure like the CAMCOG does produce results in terms of explaining the variance of health status. Compared with the extensive test batteries, screening instruments explain less of the variance but are much less timeconsuming (Visser-Keizer, 2004; Nys et al., 2006).

In our study, the amount of explained variance was least for psychosocial health status. Psychosocial functioning is a much broader and more complex area of human functioning than physical functioning. Personal factors, like coping skills, social environment and social support might influence psychosocial functioning. Larson et al. (Larson et al., 2003) stated that social support might attenuate the effect of cognitive impairment on life satisfaction. The effect of coping skills on quality of life has been supported by a study by Darlington et al. (2007). They showed that for a specific group of patients (those returning home after rehabilitation), coping skills after 5 months were more important 
determinants of quality of life than general functioning, indicating that personal factors might be much more closely related to quality of life than stroke-related factors. How this relation develops in the course of time, and to what extent this relation persists after 1 to 3 years, remains unclear.

For a proper interpretation of our findings, some limitations need to be considered. First, our study population was a selective group of stroke patients, namely those admitted to inpatient rehabilitation. This population is characterized by being quite young, with cognitive functions on a relatively high level and motor functions on a relatively low level. However, the median total CAMCOG score in our study (90) was similar to the figure (87.0) found in a hospital-based population (Kwa et al., 1996), suggesting similar levels of cognitive functioning. Nevertheless, patients with severe cognitive or communication dysfunction did not contribute to the data. Although this is inevitable in a study using self-report measures to rate the health status, this hampers the possible opportunities to generalize the results of our study to broader stroke population. Moreover, relationships between cognitive functioning and health status might be underestimated, as a result of the limited range of cognitive functioning scores. Second, measurement of cognitive impairments and treatment choice might be related. We could not include this relation in our study, as our data were collected for research purposes only and we do not have any information about the cognitive assessments that were done during rehabilitation treatment or the treatment decisions based on that assessment.

Third, we used a screening instrument which is more exhaustive than instruments like the MMSE, but not as exhaustive as a battery of cognitive tests. The CAMCOG, however, is a valid instrument to detect cognitive problems of stroke patients (De Koning et al., 1998). As our research question was to evaluate the value of cognitive screening in predicting long-term health status, the CAMCOG was very useful. A neuropsychological test battery might be the instrument of preference for clinical use which involves specific questions about cognitive functioning and aspects like returning to work, or for more educational purposes for patient and relatives.

\section{Conclusion}

The CAMCOG scores were significant predictors of longterm health status 1 and 3 years after stroke, although the amount of explained variance was small. Including other factors, like personal factors, may improve the prediction of health status after stroke.

\section{References}

Back FZ, Post MW, Velden van der H, Schepers VP, Visser-Meilly JM (2006). De spontane Communicatieschaal van het Utrechts Communicatie Onderzoek: een valide screener van communicatieve vaardigheden. [The spontaneous communication scale of the Utrechts Communicatie Onderzoek: a valid screener for communicative abilities]. Revalidata 133:5-8.

Collen FM, Wade DT, Bradshaw CM (1990). Mobility after stroke: reliability of measures of impairments and disabilities. Int Disabil Stud 12:6-9.
Collin C, Wade DT, Davies S, Horne V (1998). The Barthel ADL Index: a reliability study. Int Disabil Stud 10:61-63.

Darlington AE, Dippel DW, Ribbers GM, Balen van R, Busschbach JJ (2007). Coping strategies as determinants of quality of life in stroke patients: a longitudinal study. Cerebrovasc Dis 23:401-407.

De Koning I, van Kooten F, Dippel DW, van Harskamp F, Grobbee DE, Kluft C et al. (1998). The CAMCOG: a useful screening instrument for dementia in stroke patients. Stroke 29:2080-2086.

Derix MM, Hofstede AB, Teunisse S, Hijdra A, Walstra GJ, Weinstein HC, et al. (1991). CAMDEX-N; the Dutch version of the Cambridge Examination for Mental Disorders of the elderly with automatic data processing. Tijdschr Gerontol Geriatr 22:143-150.

Dick JPR, Guilford RJ, Stewart A, Blackstock J, Bielawska C, Paul EA Marsden CD (1984). Mini-mental state examination in neurological patients. J Neurol Neurosurg Psychiatry 47:496-499.

Haacke C, Althaus A, Spottke A, Siebert U, Back T, Dodel R (2006). Long-term outcome after stroke. Evaluating health-related quality of life using utility measurements. Stroke 37:193-198.

Heruti RJ, Lusky A, Dankner R, Ring H, Dolgopiat M, Barell V, et al. (2002). Rehabilitation outcome of elderly patients after a first stroke: effect of cognitive status at admission on the functional outcome. Arch Phys Med Rehabli 83:742-749.

Hochstenbach J, Anderson P, van Limbeek J, Mulder TT (2001). Is there a relationship between neuropsychologic variables and quality of life after stroke? Arch Phys Med Rehabil 82:1360-1366.

Jonkman EJ, de Weerd AW, Vrijens NL (1998). Quality of life after a first ischemic stroke. Long-term developments and correlations with changes in neurological deficit, mood, and cognitive impairment. Acta Neurol Scand 98:169-175.

King RB (1996). Quality of life. Stroke 27:1467-1472.

Kwa VIH, Limburg M, de Haan R (1996). The role of cognitive impairment in the quality of life after ischaemic stroke. J Neurol 243:599-604.

Larson EB, Kirschner K, Bode RK, Heinemann AW, Clorfene J, Goodman R (2003). Brief cognitive assessment and prediction of functional outcome in stroke. Top Stroke Rehabil 9:10-21.

Nys GMS, Zandvoort van MJE, Kort de PLM, Jansen BPW, Kapelle LJ, Haan de EHF (2005). Restrictions of the mini mental state examination in acute stroke. Arch Clin Neuropsychol 20:623-629.

Nys GM, van Zandvoort MJ, van der Worp HB, De Haan EF, de Kort PL, Jansen BP, Kappelle LJ (2006). Early cognitive impairment predicts long-term depressive symptoms and a reduced quality of life after stroke. J Neurol Sci 247:149-156.

Patel MD, McKevitt C, Lawrence E, Rudd AG, Wolfe CD (2007). Clinical determinants of long-term quality of life after stroke. Age Aging 36:316-322.

Roth M, Tym E, Mountjoy CQ, Huppert FA, Hendrie H, Verma S, Goddard R (1986). CAMDEX: a standardized instrument for the diagnosis of mental disorder in the elderly with special reference to the early detection of dementia. Br J Psychiat 149:698-709.

Sturm JW, Donnan GA, Dewey HM, Macdonell RA, Gilligan AK, Srikanth V, Thrift AG (2004). Quality of life after stroke. The North East Melbourne Stroke Incidence Study (NEMESIS). Stroke 32:2340-2345.

Surh JA, Grace J (1999). Brief cognitive screening of right hemisphere stroke: relation of functional outcome. Arch Phys Med Rehabil 80:773-776.

Te Winkel-Witlox AC, Post MW, Visser-Meily JM, Lindeman E (2008). Efficient screening of cognitive dysfunction in stroke patients: comparison between the CAMCOG and the R-CAMCOG, Mini Mental State Examination and Functional Independence Measure-cognition Score. Disabil Rehabil 30:1386-1391.

Van de Port IG, Ketelaar M, Schepers VP, Van den Bos GA, Lindeman E (2004). Monitoring the functional health status of stroke patients: the value of the Stroke-Adapted Sickness Impact Profile-30. Disabil Rehabil 26:635-640.

Van Straten A, de Haan RJ, Limburg M, Schuling J, Bossuyt PM, van den Bos GA (1997). A stroke-adapted 30-item version of the Sickness Impact Profile to assess quality of life (SA-SIP30). Stroke 28:2155-2161.

Van Straten A, de Haan RJ, Limburg M, van den Bos GA (2000). Clinical meaning of the Stroke-Adapted Sickness Impact Profile-30 and the Sickness Impact Profile-136. Stroke 31:2610-2615.

Van Zandvoort MJ, Kessels RP, Nys GM, de Haan EH, Kappelle LJ (2005). Early neuropsychological evaluation in patients with ischaemic stroke provides valid information. Clin Neurol Neurosurg 107:385-392.

Visser-Keizer AC (2004). The impact of emotional and cognitive changes after stroke: a longitudinal community based study. Groningen: University Library Groningen. 